Joanna Joachimiak-Prażanowska

Uniwersytet Kazimierza Wielkiego w Bydgoszczy

Wydział Humanistyczny

Instytut Neofilologii i Lingwistyki Stosowanej

tel. +48523411402

e-mail: joanna.j-p@wp.pl

ORCID ID: https://orcid.org/0000-0002-9924-3306

\title{
Kilka uwag o zjawiskach z zakresu konsonantyzmu w międzywojennej polszczyźnie północnokresowej (na przykładzie Kuriera Wileńskiego)
}

Słowa kluczowe: dwudziestolecie międzywojenne, polszczyzna północnokresowa, fonetyka, konsonantyzm

Polszczyzna funkcjonująca na terenach dawnych polskich Kresów północno-wschodnich wyraźnie odróżnia się od języka ogólnopolskiego. Ta odmienność - jak podkreśla Stanisław Dubisz - wynika „przede wszystkim z substratu języków (dialektów) wschodniosłowiańskich oraz innych niż w Polsce centralnej uwarunkowań jej rozwoju" [Dubisz 2014, 8].

Jednym z najbardziej zróżnicowanych językowo, a także kulturowo i etnicznie jest obszar Kresów zwany Wileńszczyzną. Krzyżują się tu cztery języki o różnym stopniu pokrewieństwa. Na co dzień ludność polska zamieszkująca Wilno i południowo-zachodnią Litwę posługuje się językiem litewskim - jako państwowym, a także polskim, rosyjskim i tzw. prostym

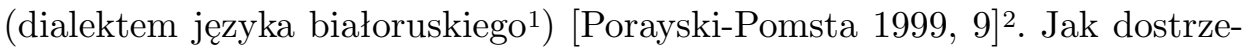
ga Józef Porayski-Pomsta owa ,złożoność sytuacji językowej to nie tylko kwestia wielu języków, które występują na jednym wspólnym terytorium, to przede wszystkim zagadnienie polilingwizmu większości mieszkańców Litwy,

\footnotetext{
1 Por.: [Mędelska, Sawaniewska-Mochowa 1997].

2 Szerzej o wspólistnieniu języków na terenach byłego Wielkiego Księstwa Litewskiego zob.: [Koniusz 2013, 41-42].
} 
gdzie w sposób niemal dotykalny można rzeczywiście sprawdzić, co oznacza kontakt językowy: ów polilingwizm - zwłaszcza osób zamieszkujących na Wileńszczyźnie - jest przyczyną wielu zjawisk językowych, takich m.in. jak wzajemne wpływy poszczególnych systemów językowych, co w konsekwencji znajduje swoje odbicie w zachowaniach językowych użytkowników języków będących w kontakcie" [Porayski-Pomsta 1999, 10].

Stan kulturalnego wariantu języka polskiego na Wileńszczyźnie został już dziś dość dobrze udokumentowany ${ }^{3}$. Publikacje i liczne artykuły traktują przede wszystkim o historii tej regionalnej odmiany języka ${ }^{4}$, polszczyźnie powojennej $^{5}$ i współczesnej ${ }^{6}$. Warto jednak odtworzyć brakujące ogniwo, spajające wiek XIX z okresem powojennym, ponieważ wiedza o polszczyźnie wileńskiej dwudziestolecia międzywojennego ${ }^{7}$ pozostaje nadal fragmentaryczna.

W niniejszym artykule przedstawię wybrane zjawiska fonetyczne z zakresu konsonantyzmu, występujące w języku Kuriera Wileńskiego w latach 1924-1939. Są to spółgłoski płynne, czyli mieszanie zakresów użycia $l$ i $l$, udźwięcznianie $s$ oraz geminacja (podwajanie spółgłosek) i degeminacja, czyli brak podwojeń. Spośród ważniejszych zagadnień zaobserwowanych w badanym czasopiśmie trzeba również wymienić: dystrybucję spółgłosek twardych i miękkich (m.in. palatalizację: Ulegt [...] źmianie skład drużyny WKS - 34/310/48; Buchnęly radośne śpiewy - 26/180/2 lub jej brak w grupach spółgłoskowych: Puste naczynia dzwięcza - 36/70/7; Smietanka musi być na wierzchu - 28/80/5 oraz wahania n//ń: Okoliczne goścince [...] sq zalane - 32/80/4; [...] spodeńki sq za ciasne - 34/180/4), dystrybucję spółgłosek zębowych i dziąsłowych (m.in. spółgłoskę $̌$ jako odpowiednik ogpol. $s:[\ldots]$ szmalec wieprzowy [...] - 24/43/4, spółgłoskę $s$ na miejscu ogpol. $\check{s}:$ On nie mieska $w$ chacie [...] - 37/260/5, spółgłoskę $\check{z}$ jako odpowiednik ogpol. $z$ : [...] byt żupetnie pijanym [...] - 26/250/4, spół-

3 Zob. bibliografie, sporządzone przez Zofię Sawaniewską-Mochową [1991, 223-254; 1995, 265-282] oraz Jolantę Mędelską [MędJP II 2000, 617-649; MędJP-III (1) 2004, 1024-1071].

4 Por. również niektóre ważniejsze opracowania: [Turska 1930], [Trypućko 1955], [Trypućko 1957], [Kurzowa 1993].

5 Zob. m.in. monografie: [Mędelska 1993], [MędPW 1999], [MędJP II 2000], [MędJP-III (1) 2004].

6 Por. też opracowania: [Dawlewicz 2000], [Masojć 2001] oraz artykuły: [Nagórko 1992], [Sordyl, Witkowski 1993].

7 Por. m.in. pracę z tego okresu: [Szwed 1931] oraz artykuły: [Nitsch 1925]; [Turska 1930]; [Sykulski 1935/36]. Zob. także artykuły współczesnych badaczy dotyczące dwudziestolecia międzywojennego, m.in: [Joachimiak-Prażanowska 2010], [Joachimiak-Prażanowska 2013].

8 Cyfry w tym zapisie oznaczają kolejno: rok wydania Kuriera Wileńskiego, numer, stronę. 
głoskę $z$ na miejscu ogpol. $\check{z}$ : [...] wykradli bizuterje - 24/69/3, spółgłoskę č jako odpowiednik ogpol. c: [...] wokót porozrzuczana słoma $[\ldots]-32 / 180 / 3$, spółgłoskę $c$ na miejscu ogpol. $\check{c}$ : Taki to byt cłowiek - 37/200/4), a także mieszanie spółgłosek szumiących i ciszących (m.in. spółgłoskę $\breve{s}$ jako odpowiednik ogpol. ś: [...] przyszla swe delegacje [...] - 29/90/1, spółgłoskę ś na miejscu ogpol. š: [...] przyśli profesorowie [...] maja poważne watpliwości - 24/124/4, spółgłoskę ź jako odpowiednik ogpol. $\check{z}:[\ldots]$ wspomniałem tylko pobieźnie [...] - 37/1/2, spółgłoskę ž na miejscu ogpol. ź w grupach spółgłoskowych: [...] coś bełkotat niewyrażnego - 35/140/5). Ze względu na brak miejsca przedstawiam tu tylko część wyekscerpowanego materiału. W minimalnym zakresie prezentuję też konteksty, które ilustrują funkcjonowanie danej cechy fonetycznej.

Po materiał językowy sięgnęłam do gazety codziennej, ukazującej się w stolicy Kresów północno-wschodnich w dwudziestoleciu międzywojennym. Założycielem i pierwszym jej redaktorem był Aleksander Kleczkowki.

Kurier Wileński jako organ miejscowej prasy ,[...] należał do grona trzech największych dzienników wileńskich, kreujacych opinię społeczną. Na jego łamach łatwo odnaleźć echa wszystkich najważniejszych wydarzeń artystycznych i kulturalnych. Recenzje i sprawozdania z teatrów i sal koncertowych, anonse spotkań kulturalnych, dyskusji, wystaw itp. Jako dziennik społeczno-polityczno-kulturalny ograniczał się wprawdzie głównie do roli informacyjnej, nie stronił jednakże od podejmowania dyskusji i polemik w kwestiach spornych. Redakcja zamieszczała artykuły i felietony krytyczno-literackie, prezentowała sylwetki znanych twórców literatury, jak i artystów plastyków" [Janik, Jarowiecki 2004, 79].

$\mathrm{Z}$ badanego czasopisma okresu międzywojennego wynotowałam te formy wyrazowe, których postać graficzna nie była akceptowana przez ówczesne źródła normatywne. Mogła zatem odzwierciedlać lokalną wymowę, specyficzną na tle ogólnopolskim. Zgromadzone osobliwości fonetyczne zostały zaczerpnięte z prasy, czyli z tekstów drukowanych, a nie z języka mówionego. Jak pisze Jolanta Mędelska: „Fakt ten może rodzić wątpliwości co do podłoża wynotowanych zmian. Brakuje mianowicie pewności, czy specyficzna postać graficzna odzwierciedla rzeczywistą wymowę danej formy, czy też świadczy jedynie o zastosowaniu osobliwej grafii. Całkowite wyeliminowanie tego rodzaju wątpliwości jest niemożliwe, jednak prezentacja materiału na szerokim tle porównawczym, zarówno ogólnopolskim, jak i północnokresowym, powinna pomóc w rozwiązaniu znacznej ich części” [Mędelska 2000, 14]. Mając powyższe na uwadze, omawiając wybrane zagadnienia fonetyczne z zakresu konsonantyzmu, informuję o wcześniejszych zapisach w języku 
ogólnopolskim. Sprawdzam, czy zjawisko nie występowało na Kresach północno-wschodnich już dawniej lub obecnie. Prezentuję także poświadczenia żywotności danej cechy w powojennej polszczyźnie wileńskiej (radzieckiej). Poczynione obserwacje podaje w postaci krótkich podsumowań.

W artykule prezentuję zatem spółgłoski płynne, udźwięcznianie $s$ oraz geminaty. Pomijam zaś zjawiska dotyczące palatalizacji i dyspalatalizacji spółgłosek oraz wahania w doborze spółgłosek szeregu szumiącego, syczącego i ciszącego. W badanym materiale odznaczały się one stosunkowo dużą frekwencją i zostały szczegółowo opisane w innym miejscu.

\section{Spółgłoski płynne}

\section{Mieszanie zakresów użycia $l$ i $t$}

a) $\boldsymbol{t}$ jako odpowiednik ogpol. $\boldsymbol{l}$ :

- Kraszewski btednie wobec nowej sity Sienkiewicza [...] - 24/125/3; [...] nic prócz chteba $i$ wody do ust nie brat - 26/230/2; Kto dat prawo panu krytykowi [...] nazywać mnie „reklamujacym sie dytetantem" - 25/200/4; [...] ftota battycka - 24/3/3; Ftota powietrzna [...] - 39/300/1; [...] ideotogia białoruska - 38/180/6; Na środku nawy głównej [...] symboliczny katafatk [...] - 29/160/2; [...] za krata ktatki $[\ldots]-24 / 1 / 4$; [...] odezwatem sie o kołeżeństwie w pracy [...] - 24/129/3; Pośród [...] hołdów Państw i przyjęć u krótow-38/110/4; Wiek 18-24 lat względnie 26 tat $[\ldots]$ - 24/33/2; Owacje [...] w Eondynie - 30/180/1; Do nauczycieta muzyki przychodzi [...] jegomość-38/340/4; Nieprzekraczatny wiek 50 lat życia-29/200/4; Oddziełne plaże - męska i damska - 25/120/1; Na terenie ogółno-europejskiego porozumienia [...] - 24/144/2; Lokatorzy opuściti lokal [...] - 24/30/3; Ptotto sie to i sypato, przecinajac i placzac [...] - 27/1/4; Co kosztuje wiza Potska? - 24/127/3; [...] Potska [...] wkracza w nowy okres [...] - 25/190/2; [...] skierowano do szkót potskich [...] - 26/70/3; [...] skonfiskowano „Nasz Przegtad" [...] - 30/190/2; [...] krzewy przydrożne zlewaty sie [...] $z$ nisko rozściełajacym sie puchem śnieżnym - 24/120/2; Policja aresztowała mściwa matżonke, która [...] przyznała się do wychtostania [...] rywatki [...] - 24/36/4; [...] wynajmuje się satę $w[\ldots]$ domu ludowym [...] - 29/170/3; Rzad organizuje specjatna wycieczke [...] - 25/130/2; [...] w kabarecie stotikowym [...] - 24/54/2; W szkote nie ma większej sali [...] - 29/170/3; [...] Ministerstwo ustała [...] warunki [...] - 39/10/6; [...] w Witnie [...] - 24/130/6; Wtaścicieł otrzymat 548.450 franków-24/11/2; Wołałbym,

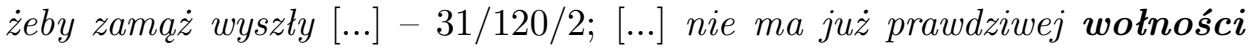
słowa - 29/180/1; [...] miasto było jedynie wspótnikiem [...] - 39/260/4; 
Miasto [...] jest [...] załane woda - 31/100/2; [...] nie ma [...] bardziej zamyśtonego narodu... - 27/1/4;

b) $\boldsymbol{l}$ jako odpowiednik ogpol. $\boldsymbol{t}$ :

- [...] policja aresztowala - 24/72/3; [...] rzad czyni wysitki stworzenia zwiazku balkańskich państw [...] - 24/147/2; [...] wyjeżdza na konferencje państw Baltyckich $-39 / 290 / 2 ;$ [...] państwa baltyckie $[. .]-.25 / 90 / 1$; [...] nad Baltykiem - 25/90/1; Hutchinson byl to rezydent [...] - 29/200/4; „Kur. Wil." powinien bylby umieścić to „oświadczenie” - 24/129/2; [...] w programie nie bylo - 25/200/4; Cala sprawa jest [...] w stadjum dyskusji - 26/240/3; Ostrze mowy zwrócone było przeciwko inżynierowi [...], którego mec. [...] chlostat cięzka ironja - 25/80/3; Do sprzedania $37 \mathrm{mtr}$. kamieni $[. .$.$] na cokol - 32/110/4; [...] masy obywateli dzialaja bez [...]$ przerwy - 39/250/1; [...] przystęuje do dzialania - 39/90/1; List ten nadszedt z gluchej prowincji - 37/120/3; [...] odpowiednio ujęta role stodkiej, glupawej $[. .$.$] Meli [...] - 35/80/5; [...] wegiel [...] pali sie na haldach [...]$ - 24/34/1; [...] 36 ilustrow. kart do wróż. i kabaly zt 1-24/106/6; Zebranie kapituly orderu „Polonia Restituta” - 24/107/3; [...] zwróciła się do kaplana [...] - 35/20/6; [...] właczyć się do kolchozów [...] - 30/190/3; [...] zaświadczenie [...] Kólka Rolniczego [...] - 26/180/4; Wesole doliny [...] optynięte [...] zielenia lak $[\ldots]-30 / 240 / 3 ;[\ldots]$ terytorjum Lotwy $[\ldots]$ - 29/170/4; Potężny trójgtós milości [...] - 27/30/4; [...] Zrzeszenie Producentów Nabialu [...] - 39/150/8; Silna nawalnica nawiedzita [...] wybrzeże [...] - 33/320/1; [...] znaleziono podrzutka plci męskiej- 25/170/4; A z drugich sportów to jest [...] krokiet, plotki [...] i narty [...] - 31/170/2; [...] patrzac spod plowej czupryny - 37/260/5; [...] polaczenie kolejowe [...] - 29/40/1; [...] pracujac za polowe ceny - 29/150/2; [...] w pierwszej polowie XIX stulecia [...] - 24/124/2; W poludnie [...] - 24/112/2; Pomyślal [...] i zrobiło mu to przyjemność [...] - 29/160/3; Na ścianie wisiały portrety [...] pralata $[. .]-.24 / 130 / 3 ;$ [...] stat sie jednym z najznaczniejszych przemyslowców $[. .]-.30 / 300 / 1 ;[. .$.$] rozpocząl się pierwszy bieg [. .$. - 29/200/3; Dobrze grali skrzydlowi [...] - 36/170/5; [...] umiejacych sie postugiwać slowem drukowanem [...] - 25/170/4; [...] ztudnym fajerwerkiem slów [...] - 29/220/1; Przypuszczenia [...] okazaty się sluszne - 35/150/2; [...] co stalo się $z$ tupem bandy - 24/112/1; [...] stosowaly z powodzeniem podwójna zmiane [...] - 24/4/3; Za szczególowa przepowiednie [...] opłata od 2 zt-33/200/4; [...] co do szczególów [...] - 24/35/4; [...] zwiedzit szkolę pielegniarska [...] - 29/170/4; Nie uplynęło paru minut, gdy [...] rozlegt sie krzyk [...] - 34/140/9; [Zarzuty] Egipt uznal za nieuzasadnione $-29 / 20 / 4 ;[.$.$] stado owcze, pachnace welna [\ldots]-27 / 1 / 4 ;[\ldots]$ film 
„gangsterowski” na wesolo - 39/80/6; [...] wśród urzędników tej centralnej wladzy [...] - 26/150/2; Rzadka i wyblakla nać kartofli - 29/150/2; [Mleko] kot wychleptat $w$ jednej chwili-24/8/2; [...] wyglad [...] przybyłej, jak i recepta wydaly sie aptekarzowi podejrzane - 35/150/2; [...] wyjechal do Kowna-28/160/1; „Zaczęla się rewolucja” - 34/60/1; Na wyróżnienie zasluguje [...] - 26/240/4; [...] śledzenie zlodziei $[. .]-.24 / 47 / 4 ;$ Śledzie [...] będa clone po 16 zlotych od beczki - 35/60/6; [...] zostalo postanowione [...] - 24/121/3; [...] zostaly wyrzadzone olbrzymie szkody [...] - 36/250/7; $[\ldots]$ nosity sie z zamiarem zwolania $[\ldots]$ kongresu $[\ldots]-33 / 110 / 2$.

Wahania $l / / t$ występowały jeszcze w XIX-wiecznym języku ogólnopolskim. Na Kresach północno-wschodnich ${ }^{9}$ - pod wpływem obcych systemów fonetycznych - do zmian dochodziło częściej (zob. MędJP-II 4310). Substytucje $l / / l$, bardzo wyraziście odzwierciedlone w „Kurierze Wileńskim”, mogły być pozostałością po ubiegłowiecznym stanie ogólnopolskim, mogły też występować pod wpływem obcym (zarówno fonetycznym, jak i leksykalnym, por. postaci: fłota, ideołogia, katafałk, Łondyn, sała, cokol i ich białoruskie oraz rosyjskie odpowiedniki: флот, ідэалогія, катафалк, Лондан, зала, цокаль; флот, идеология, катафалк, Лондон, зал, чокол. Liczne formy z osobliwym $t$ w pozycji przed spółgłoską czy samogłoską nieprzednią mogły odzwierciedlać litewskie nawyki wymawianiowe.

Wahania $l / / l$ znalazły odbicie także w powojennej prasie wileńskiej. Ujawniły się w innych słowoformach i zaznaczyły się słabiej niż w „Kurierze Wileńskim" (zob. MędJP-II 43-44 i MędJP-III 72-74; por. tė̇ w MędPW 31-32 zaledwie dwa przykłady ${ }^{11} \mathrm{z}$ tużpowojennej „Prawdy Wileńskiej”).

W „Kurierze” z lat 20. dostrzeżono 64 postaci z osobliwą spółgłoską płynną, natomiast w rocznikach $\mathrm{z}$ lat 30 . wystąpiły 34 takie formy.

\section{Udźwięcznianie $s$}

- [...] latem tlumy chętnie wchtaniaja ten balzam miast wieku XX-go - 24/124/4 i 30/60/412; [...] w celach defenzywnych - 33/260/2; [...] przygotowuje pierwsza tranzakcje - 39/20/2.

9 Zdaniem Alicji Pihan-Kijasowej jest to „cecha występująca u wielu autorów kresowych" [Pihan-Kijasowa 1999, 35].

10 Rozwiązanie wprowadzonych skrótów zamieszczam na końcu artykułu.

11 Oba ilustrują tylko zamianę $l$ na $t$, poświadczeń odwrotnych nie zanotowano.

12 W takiej postaci notuje SL (z odsył. do balsam). Przed jej używaniem ostrzega Julian Szwed [Szwed 1931, 12]. Na Kresach północno-wschodnich mógł to być rusycyzm: бальзам. 
Udźwięcznianie $s$ (po $l$ i $n$ ) w wyrazach obcego pochodzenia obserwowano w tych regionalnych odmianach polszczyzny, które znajdowały się pod wpływem języka niemieckiego (zob. MędJP-III 75). W „Kurierze Wileńskim" cecha ta odzwierciedliła się niezbyt wyraziście, podobnie było w powojennej prasie wileńskiej (MędJP-III 75-76 13 ).

$\mathrm{Z}$ lat 20. pochodzi jeden przykład, z lat $30 .-3$ przykłady.

\section{Geminaty}

\section{A. Podwajanie spółgłosek}

a) w wyrazach obcych:

- Przez assocjacje [...] - 24/142/2; Najlepszy assortyment futer [... - 24/118/1; Zastaliśmy profesora nad assyryjskimi mapami - 24/124/4; Dessent jest [...] trudniejszy niż obrona - 39/171/1; Dyskusja o tem stataby sie jałowa dyssertacja akademicka - 24/129/3; [...] to wspomnienie, w essencji swej wtaściwie martwe [...] - 26/100/1; [...] Finnowie lubia porzadek [...] - 39/169/5 oraz 39/290/2 (4 razy), 39/300/1, 39/110/4; Gaffa „Dz. Nar.” polega na założeniu, że [...] - 35/250/2; [...] popetnili znów [...] "gaffe" - 39/60/1; [...] kwitty pośród skat [...] szafirowe oczy Tatr: gencjanny - 39/1/3; [...] w halli miejskiej [...] - 24/107/4; - Hallo, hallo $[\ldots]$ - 33/50/2; Polacy na ryskim hippodromie - 36/250/7; Jako mtodziutka dziewczyna przeżyła insurrekcje [...] - 37/20/6; [...] intrygi kamarylli dworskiej Francji [...] - 28/230/4; [...] kollektywizm gospodarczy [...] - 29/150/1; [Student] odwala kollokwia - 31/280/1; [...] musi przeprowadzić korrekte [...] - 27/120/2; Poset niemiecki u minnistra Zaleskiego - 29/240/2; Duży wybór [...] nesseserów - 29/290/1; [...] w passażu [...] miat miejsce [...] wypadek - 34/240/2; [...] choroba passywnego bilansu [...] - 28/200/4; [...] okazja taniego kupna [...] pullowerów $[. .]-.28 / 260 / 4 ; \mathrm{Na}$ siona koniczyn $[\ldots]$, seradelli $[\ldots]-26 / 70 / 1$; Lubiny $[\ldots]$ oraz seradelle poleca Zygmunt Nagrodzki - 27/120/4; [...] specjalnie skonstruowany stopper $[\ldots]-36 / 30 / 7$ (2 razy); [...] staje sie [...] wchtaniajaca suggestywnie w siebie słowa mówcy - 29/210/1; jedenaście razy wystąpiła postać tonna ([...] 600 czołgów [...] majacych po 70 tonn wagi - 39/250/2 oraz $24 / 6 / 2$, 26/180/1, 27/20/4, 28/10/2 (2 razy), 28/20/3 (4 razy), 28/230/4, 29/20/2, $30 / 90 / 4,31 / 60 / 3,35 / 10 / 5)$;

13 Przykłady udźwięczniania $s$ wystąpiły dopiero w latach 1960-1979 (m.in. właśnie balzam i defenzywa). 
b) w wyrazach rodzimych:

- [...] wbiegt na podwórko przyległej kamiennicy - 35/330/8; Kuppit tombakowe obraczki [...] - 33/180/4; [...] wypadki potocza się z piorunnująca szybkościa - 39/250/1; [...] nie powinienneśs wypowiadać abonamentu [...] - 38/200/5; Rycerska to stannica $[. .]-.33 / 310 / 2$.

Redaktorzy Kuriera Wileńskiego zapisywali podwójnie głównie spółgłoski w wyrazach obcego pochodzenia, czyli być może zgodnie z dawną, nieaktualną zasadą polskiej ortografii (zob. MędJP-II 45). Jednocześnie niemal wszystkie postaci osobliwe mają odpowiedniki w formach graficznych wyrazów rosyjskich: алло, ассочиачия, ассортимент, ассирийский, диссертация, финн, коллоквиум, ипподром, коллективизм, корректура, несессер, пассаж, пассивный, сераделла, стоппер, тонна, mogły więc pojawiać się pod ich wpływem. Jednak tylko nieliczne z tych rosyjskich postaci odzwierciedlają rzeczywistą wymowę geminaty (między samogłoskami po sylabie akcentowanej): сераделла, стоппер, тонна. Tak więc spółgłoski zdwojone w wyrazach obcych to raczej zakłócenia graficzne, a nie fakty wymowy. Niemniej trzeba też rozważyć możliwość wystąpienia tzw. literalnej wymowy, tj. wymowy zgodnej $\mathrm{z}$ formą graficzną. Zjawisko to obserwuje się współcześnie u inteligencji wileńskiej „niepewnej poprawności swojej fonetyki" ${ }^{14}$. Natomiast wypadki podwajania geminat w wyrazach rodzimych odzwierciedlają znamienną cechę fonetyki północnokresowej, ukształtowaną pod wpływem języka białoruskiego (dla którego geminacja jest charakterystyczna) lub - wskutek przesady poprawnościowej - pod wpływem języka litewskiego (w którym nie ma spółgłosek zdwojonych).

W powojennej prasie wileńskiej zjawisko podwajania spółgłosek wystąpiło w mniejszym natężeniu (było jednak zauważalne $\mathrm{w}$ tużpowojennej Prawdzie Wileńskiej15). Osobliwa geminacja dotyczyła - podobnie jak w Kurierze Wileńskim - głównie wyrazów obcych. Tylko jedna postać ujawniła się $\mathrm{w}$ obu źródłach: tonna (zob. MędJP-II 44-45 i MędJP-III 77-78).

W Kurierze z lat 30. liczba postaci osobliwych nieznacznie się zmniejszyła (lata 20 -te -27 przykładów, lata 30-te - 26).

14 Zob. [Dwilewicz 1999, 145].

15 Zob. MędPW 32. 


\section{B. Brak ogólnopolskich podwojeń}

a) w wyrazach obcych:

- [...] nie mógt sie pogodzić z taka inowacja ${ }^{16}$ [...] - 29/60/2 oraz $24 / 43 / 3,29 / 60 / 2,29 / 150 / 2,30 / 280 / 3,33 / 70 / 2,34 / 190 / 1,34 / 90 / 2$, $37 / 200 / 4,39 / 90 / 3$; [...] dar naracyjny [...] - 25/190/2; Steroryzowanemu St. zrabowano skrzynie [...] - 24/46/3; [...] teroryzowanie wtaścicieli - 30/110/2; [...] teroryzuje miasto - 39/20/6;

b) w wyrazach rodzimych:

- [...] postawiona zostanie bezwtocznie [...] - 39/90/4; [...] ludność prawostawna Wilna oraz inowiercy [...] - 39/20/4; Miłość mężczyzny czyni $z$ kobiety męczenice - 26/260/3; [...] majatek towarzystwa nie zostat podany kontroli $[. .]-.24 / 6 / 1 ;[.$.$] kobiety [\ldots]$ sie rozuchwality $[\ldots]-39 / 171 / 6$; Na tóżku ze zwyktym sienikiem brakowało poszewek [...] - 37/200/4; Zjazd uczenic szkoty handlowej - 29/110/3 oraz 24/135/3, 26/60/4, 28/50/6, $28 / 80 / 8, \quad 29 / 120 / 2,30 / 1 / 2,30 / 200 / 4,31 / 210 / 4,34 / 70 / 2,35 / 240 / 6$, $36 / 80 / 7$ (2 razy), 36/140/4 (2 razy), 37/301/4, 38/220/8, 39/20/7, 39/37/4 (2 razy), 39/38/5, 39/130/5, 39/140/3, 39/160/3, 39/171/6, 39/290/3; [...] domagat sie uchylenia uniewiniajacego wyroku [...] - 38/330/5; [...] prosza o uniewinienie [...] - 25/80/3; Chonowicza zaś uniewiniono - 26/4/4; [Przeor] udat sie z zakonikami do pałacu [...] - 26/230/2.

O występowaniu zjawiska degeminacji w języku ogólnopolskim źródła nie informują, natomiast na Kresach północno-wschodnich notuje się je od początków XVII w. [Kurzowa 1993, 109]. Ściąganie geminat towarzyszy osobliwemu podwajaniu spółgłosek, jest jego odwrotnością, zatem u podłoża tego zjawiska leżą te same przyczyny: wpływ litewski i białoruski (zob. wyżej).

W przeciwieństwie do osobliwej geminacji degeminacja ujawniała się częściej w wyrazach rodzimych niż w zapożyczeniach. Jej fonetyczny, a nie graficzny charakter jest bardziej prawdopodobny. Dochodziło do ściągania $d d, n n, z z$ - tak jak wcześniej na Kresach północno-wschodnich - w przedrostkach i przyrostkach (wyjątek: inowiercy ${ }^{17}$ ). Trzy formy rodzime mają odpowiedniki z pojedynczą spółgłoską w języku rosyjskim: иновереu, мученича і ученица.

\footnotetext{
16 MASO notuje jeszcze z jednym n (inowacja), ale odsyła do innowacja; w SO innowacja z ostrzeżeniem: nie inowacja.

17 Jest to raczej ślad starszej normy ortograficznej (w MASO mamy jeszcze obie formy, w SO - ostrzeżenie: nie innowierca).
} 
W powojennej prasie wileńskiej zagadnienie ściągania geminat odznaczało się mniejszą frekwencją niż w Kurierze Wileńskim (było jednak zauważalne w tużpowojennej Prawdzie Wileńskiej18). Powtarzały się w niej dwie postaci osobliwe znane z okresu międzywojennego: inowacja i uczenica (zob. MędJP-II 45-46 i MędJP-III 78-79).

W latach 30. osobliwe ściąganie geminat ujawniało się w badanej gazecie częściej niż w latach 20. (33 wystąpienia wobec 17). Zapewne w jakimś stopniu był to skutek przesady poprawnościowej.

\section{Wnioski}

W międzywojennym Kurierze Wileńskim wystąpiło ogółem 7 zjawisk mogących odzwierciedlać regionalną wymowę z zakresu konsonantyzmu. W niniejszym artykule szczegółowo omówiono 4 zagadnienia. Niemal wszystkie uznawane są za charakterystyczne dla polszczyzny Kresów północno-wschodnich już od kilku stuleci.

Dostrzeżone na łamach badanej gazety cechy fonetyczne w większości odznaczały się dużą frekwencją tekstową. Najsilniej uwidoczniły się spółgłoski płynne, mianowicie mieszanie zakresów użycia $l$ i $\ell$ (łącznie 98 poświadczeń). Podwajanie geminat zarówno w wyrazach obcych, jak i rodzimych, poparte zostało 53 przykładami, zaś degeminacja - 50 poświadczeniami. Słabo zaznaczyło się tylko udźwięcznianie $s$ (po $l$ i $n$ ) w wyrazach obcych. Zjawisko to nie jest jednak zaliczane do dawnych fonetyzmów północnokresowych.

Zgromadzone zagadnienia z zakresu konsonantyzmu różniły się także pod względem frekwencji tekstowej w poszczególnych okresach, co ukazuje diagram na następnej stronie.

Porównując omawiane w niniejszym artykule zjawiska fonetyczne odzwierciedlone w początkowych rocznikach Kuriera Wileńskiego (lata 1924-1929) z cechami tego czasopisma drukowanego w latach 30. dwudziestolecia międzywojennego można stwierdzić, że wraz z upływem czasu frekwencja tekstowa regionalizmów fonetycznych zmniejszyła się. Tylko dwa zagadnienia (ściąganie geminat oraz udźwięczniane $s$ : po $l$ i $n$ ) uwidoczniły się nieco silniej w rocznikach okresu późniejszego. Taki stan rzeczy nie powinien dziwić w latach odzyskania przez Polskę niepodległości, czyli w czasie wzrostu troski o czystość i poprawność języka polskiego.

18 Zob. MędPW 32-33. 
Frekwencja badanych osobliwości spółgłoskowych w latach 20. oraz 30. dwudziestolecia międzywojennego ${ }^{19}$

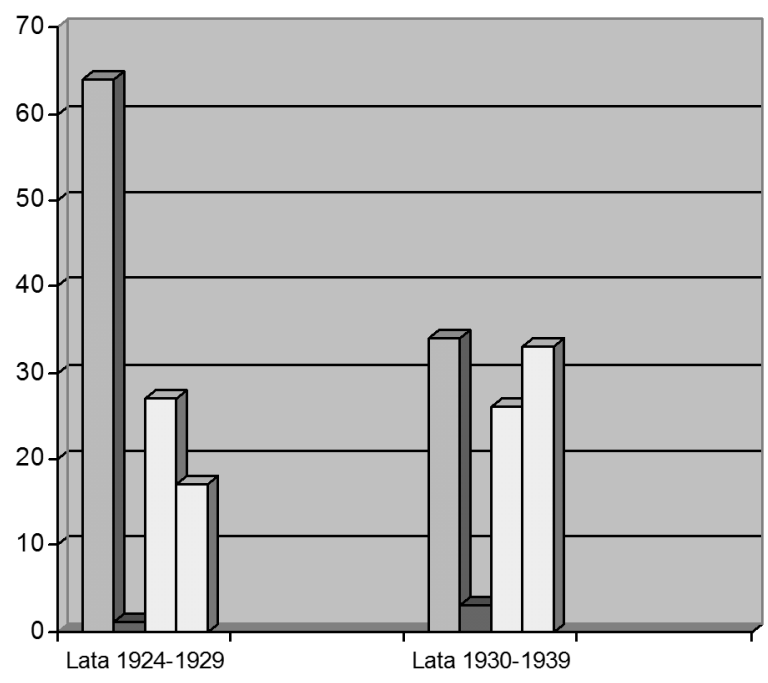

\begin{tabular}{|l}
\hline Mieszanie zakresów \\
użycia li ł \\
$\square$ Udźwięcznianie s \\
$\square$ Podwajanie spółgłosek \\
$\square$ Brak ogólnopolskich \\
podwojeń
\end{tabular}

Wyekscerpowane fonetyczne fakty językowe z obu okresów międzywojnia, uszeregowane w kolejności malejącej, przedstawiono w postaci list rangowych.

\section{Ranga pod względem frekwencji zjawisk spółgłoskowych we wcześniejszym okresie}

\begin{tabular}{|l|c|}
\hline \multicolumn{1}{|c|}{ Cecha } & $\begin{array}{c}\text { Frekwencja tekstowa } \\
\text { Lata 1924-1929 }\end{array}$ \\
\hline $\begin{array}{l}\text { Mieszanie zakresów użycia } l \text { i } l: \\
-l \text { jako odpowiednik ogpol. } t\end{array}$ & 38 \\
\hline Podwajanie spółgłosek & 27 \\
\hline $\begin{array}{l}\text { Mieszanie zakresów użycia } l \text { i } l: \\
-\ell \text { jako odpowiednik ogpol. } l\end{array}$ & 26 \\
\hline Brak ogólnopolskich podwojeń & 17 \\
\hline Udźwięcznianie $s$ & 1 \\
\hline
\end{tabular}

19 Zagadnienia spółgłoskowe podano w takiej kolejności, w jakiej zostały opisane w tym artykule. 


\section{Ranga pod względem frekwencji zjawisk spółgłoskowych w późniejszym okresie}

\begin{tabular}{|l|c|}
\hline Cecha & $\begin{array}{c}\text { Frekwencja tekstowa } \\
\text { Lata 1930-1939 }\end{array}$ \\
\hline Brak ogólnopolskich podwojeń & 33 \\
\hline Podwajanie spółgłosek & 26 \\
\hline $\begin{array}{l}\text { Mieszanie zakresów użycia } l \text { i } l: \\
-l \text { jako odpowiednik ogpol. } l\end{array}$ & 24 \\
\hline $\begin{array}{l}\text { Mieszanie zakresów użycia } l \text { i } l: \\
-\ell \text { jako odpowiednik ogpol. } l\end{array}$ & 10 \\
\hline Udźwięcznianie $s$ & 3 \\
\hline
\end{tabular}

W ekscerpcie zwraca uwagę największy udział wystąpień jednostkowych. W grupie najczęściej poświadczanych fonetyzmów północnokresowych mamy postaci: uczenica (27 wystąpień), tonna (15) oraz inowacja (10). Reprezentują one zjawiska geminacji (podwajania spółgłosek) i degeminacji (braku podwojeń).

Trzeba podkreślić, że zagadnienia z zakresu konsonantyzmu wypisane z Kuriera Wileńskiego odzwierciedliły się także w prasie wileńskiej wydawanej tuż po II wojnie światowej, jednak w nieco mniejszym natężeniu. Co ciekawe, nie wystąpiło tam zjawisko zamiany $l$ na $l$.

\section{Źródła}

„Kurier Wileński” (1924-1939)

\section{Wykaz skrótów}

MASO - Michała Arcta Słownik ortograficzny, 1934, Warszawa.

MędJP-II - Mędelska J., 2000, Język polskiej prasy wileńskiej (1945-1979). T. II. Lata 1945-1959, Bydgoszcz.

MędJP-III - Mędelska J., 2001, Język polskiej prasy wileńskiej (1945-1979). T. III. Lata 1960-1979. Cz. I. Fonetyka, słowotwórstwo, fleksja, sktadnia, Bydgoszcz.

MędJP-III (1) - Mędelska J., 2004, Język polskiej prasy wileńskiej (1945-1979). T. III. Lata 1960-1979. Cz. II. Stownictwo, wyrazy, Bydgoszcz. 
$\begin{aligned} \text { MędPW } \quad & \text { Mędelska J., 1999, Język „Prawdy Wileńskiej”. Pótnocnokresowa } \\ & \text { polszczyzna kulturalna w poczatkach sowietyzacji Wilna i Wileńsz- } \\ & \text { czyzny, Bydgoszcz. } \\ \text { SL } & \text { Linde S. B., 1807-1814, Stownik języka polskiego, t. 1-6, Warsza- } \\ & \text { wa. } \\ \text { SO } & \text { Szober S., 1937, Stownik ortoepiczny. Jak mówić i pisać po polsku!, } \\ & \text { Warszawa. }\end{aligned}$

\section{Literatura}

Dawlewicz M., 2000, Stownictwo socjolektu mtodzieży polskiego pochodzenia w Wilnie, Warszawa.

Dubisz S., 2014, Sytuacja jezyka polskiego na Litwie, Ukrainie i Białorusi, „Poradnik Językowy" nr 7 (716), s. 7-20.

Dwilewicz B., 1999, Polszczyzna inteligencji wileńskiej wobec gwar pónocnokresowych, „Acta Baltico-Slavica” XXIV, s. 143-150.

Janik M., Jarowiecki J., 2004, „Kurier Wileński” (1924-1939), „Rocznik Historii Prasy Polskiej" t. VII, z. 2 (14), s. 77-96.

Joachimiak-Prażanowska J., 2010, Rusycyzmy w „Kurierze Wileńskim” (19251939), Acta Baltico-Slavica” XXXIV, s. 121-145.

Joachimiak-Prażanowska J., 2013, Wybrane zagadnienia sktadni regionalnej w polszczyźnie „Kuriera Wileńskiego” z lat 1924-1939, „Acta Baltico-Slavica” XXXVII, s. 543-563.

Koniusz E., 2013, Wspótistnienie języków na ziemiach byłego Wielkiego Księstwa Litewskiego w świetle prac Jana Karłowicza, "Acta Baltico-Slavica” XXXVII, s. 41-51.

Kurzowa Z., 1993, Język polski Wileńszczyzny i kresów pótnocno-wschodnich $X V I-X X w$., Warszawa.

Masojć I., 2001, Regionalne cechy systemu gramatycznego wspótczesnej polszczyzny kulturalnej na Wileńszczyźnie, Warszawa.

Mędelska J., 1993, Język polski na Litwie w dziewiatym dziesięcioleciu XX wieku, Bydgoszcz.

Mędelska J., Sawaniewska-Mochowa Z., 1997, Język polski na Litwie, [w:] Dubisz S. (red.), Język polski poza granicami kraju, Opole, s. 45-68.

Nagórko A., 1992, Wpływy rosyjskie na język polskiej inteligencji wileńskiej, [w:] Kubiak H., Paleczny T., Rokicki J., Wawrykiewicz M. (red.), Mniejszości polskie i Polonia w ZSRR, Warszawa - Wrocław - Kraków, s. 139-147.

Nitsch K., 1925, Język polski na Wileńszczyźnie, „Przegląd Współczesny” nr 33, s. $25-32$.

Pihan-Kijasowa A., 1999, Literacka polszczyzna kresów pótnocno-wschodnich XVII wieku. Fonetyka, Poznań. 
Porayski-Pomsta J., 1999, O potrzebie badań nad sytuacja jezzykowa na dawnych kresach polskich, [w:] Porayski-Pomsta J. (red.), Sytuacja językowa na Wileńszczyźnie. Materiały sympozjum „Socjo- $i$ psycholingwistyczne uwarunkowania sytuacji językowej w Wilnie i na Wileńszczyźnie”. Warszawa 16-18 października 1997 roku, Warszawa, s. 9-16.

Sawaniewska-Mochowa Z., 1991, Bibliografia prac o polszczyźnie kresowej, [w:] Rieger J., Werenicz W. (red.), Studia nad polszczyzna kresowa, t. VI, Wrocław - Warszawa - Kraków - Gdańsk - Łódź, s. 223-254.

Sawaniewska-Mochowa Z., 1995, Bibliografia prac o polszczyźnie kresowej za lata 1989-1993 (z uzupetnieniami do roku 1988), [w:] Rieger J. (red.), Studia nad polszczyzna kresowa, t. VIII, Warszawa, s. 265-282.

Sordyl J., Witkowski W., 1993, Elementy obcojęzyczne w polszczyźnie „Czerwonego Sztandaru” i „Kuriera Wileńskiego” (1989-1990), „Slavia Orientalis” XLII, s. $346-349$.

Sykulski J., 1935/36, Spostrzeżenia nad błędami językowymi młodzieży szkolnej w Stonimie. „Poradnik Językowy” nr 1, s. 9-11.

Szwed J., 1931, Mów poprawnie! Stownik btędów językowych, Wilno.

Trypućko J., 1955, Język Wtadystawa Syrokomli (Ludwika Kondratowicza). Przyczynek do dziejów polskiego jezzyka literackiego w wieku XIX, T. I, Uppsala.

Trypućko J., 1957, Język Wtadystawa Syrokomli (Ludwika Kondratowicza). Przyczynek do dziejów polskiego języka literackiego w wieku XIX, T. II, Uppsala.

Turska H., 1930, Język polski na Wileńszczyźnie, [w:] Turska H. (red.), Wilno i Ziemia Wileńska, t. I, s. 219-225, Wilno.

\section{A FEW PHENOMENA RELATING TO THE CONSONANT SYSTEM IN THE INTER-WAR NORTH BORDERLAND POLISH LANGUAGE (BY THE EXAMPLE OF "KURIER WILEŃSKI")}

S U M M A R Y

In the given article one finds selected phonetic phenomena relating to the consonant system functioning in the inter-war north borderland Polish language, namely: liquid consonant, that is $l$ and $t$ usage mixing, $s$ voicing and gemination (consonant geminating) and degemination, that is the lack of gemination.

All annuals of Kurier Wileński have been explored, the annual published in the capital of Vilnius region in the period 1924-1939 and addressed to the whole Polish society.

The analysis of the language sample has proved that the gathered phonetisms are thought to have been characteristic for Polish language of north and east Borderland for a few centuries. Liquid consonants $(l$ and $l$ ) have proved to be of highest test frequency in the studied newspaper. 